\title{
BET inhibitor OTX015 targets BRD2 and BRD4 and decreases c-MYC in acute leukemia cells
}

\author{
Marie-Magdelaine Coudé ${ }^{1,2, *}$, Thorsten Braun ${ }^{1,3, *}$, Jeannig Berrou ${ }^{1}$, Mélanie Dupont ${ }^{1}$, \\ Sibyl Bertrand ${ }^{1}$, Aline Masse ${ }^{1}$, Emmanuel Raffoux ${ }^{1,4}$, Raphaël Itzykson ${ }^{1,4}$, Marc \\ Delord $^{5}$, Maria E. Riveiro ${ }^{6}$, Patrice Herait 7 , André Baruchel ${ }^{1,8}$, Hervé Dombret ${ }^{1,4}$ \\ and Claude Gardin ${ }^{1,3}$

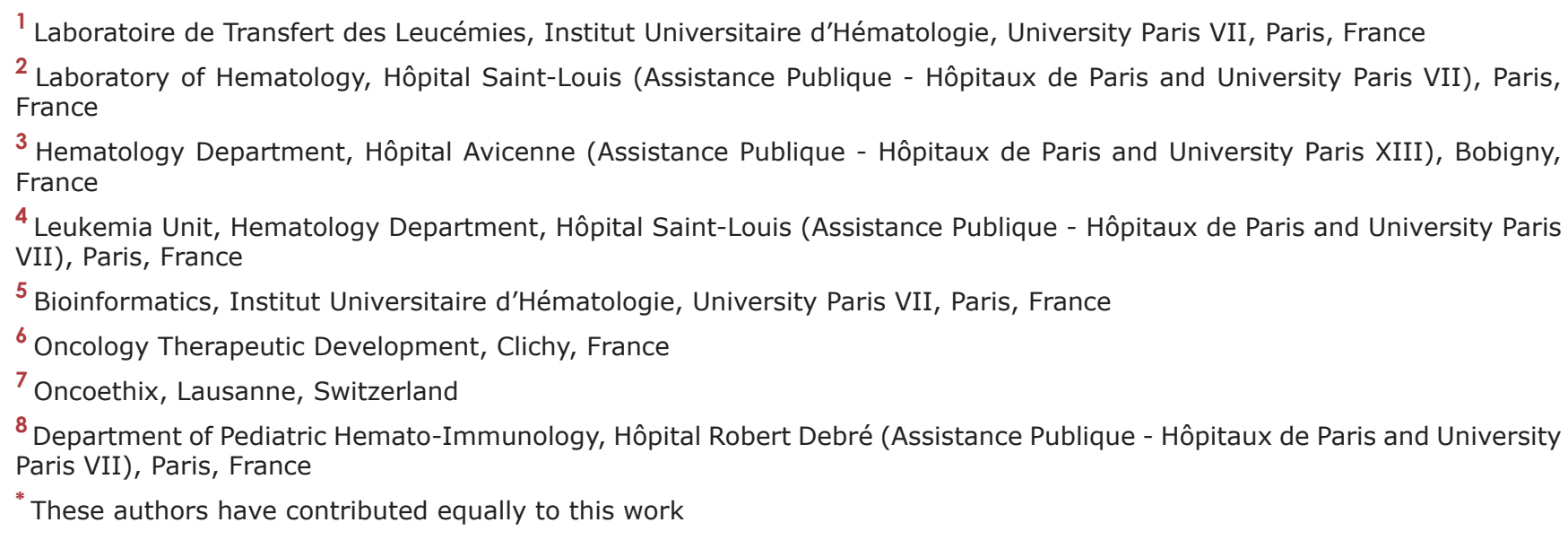

Correspondence to: Claude Gardin, email: claude.gardin@avc.aphp.fr

Keywords: OTX015, BET inhibitors, C-MYC, HEXIM1, acute leukemias

Received: November 26, $2014 \quad$ Accepted: April 08, $2015 \quad$ Published: May 14, 2015

This is an open-access article distributed under the terms of the Creative Commons Attribution License, which permits unrestricted use, distribution, and reproduction in any medium, provided the original author and source are credited.

\section{ABSTRACT}

The bromodomain (BRD) and extraterminal (BET) proteins including BRD2, BRD3 and BRD4 have been identified as key targets for leukemia maintenance. A novel oral inhibitor of BRD2/3/4, the thienotriazolodiazepine compound OTX015, suitable for human use, is available. Here we report its biological effects in AML and ALL cell lines and leukemic samples. Exposure to OTX015 lead to cell growth inhibition, cell cycle arrest and apoptosis at submicromolar concentrations in acute leukemia cell lines and patient-derived leukemic cells, as described with the canonical JQ1 BET inhibitor. Treatment with JQ1 and OTX15 induces similar gene expression profiles in sensitive cell lines, including a C-MYC decrease and an HEXIM1 increase. OTX015 exposure also induced a strong decrease of BRD2, BRD4 and C-MYC and increase of HEXIM1 proteins, while BRD3 expression was unchanged. $c-M Y C, B R D 2, B R D 3, B R D 4$ and HEXIM1 mRNA levels did not correlate however with viability following exposure to OTX015. Sequential combinations of OTX015 with other epigenetic modifying drugs, panobinostat and azacitidine have a synergic effect on growth of the KASUMI cell line. Our results indicate that OTX015 and JQ1 have similar biological effects in leukemic cells, supporting OTX015 evaluation in a Phase Ib trial in relapsed/refractory leukemia patients.

\section{INTRODUCTION}

Acute myeloid and lymphoid leukemias (AML and ALL) is a genetically complex and heterogeneous group of tumors associated with maturation arrest, expansion of abnormal hematopoietic progenitors, and abnormal remodeling of chromatin [1]. Recent reports describe a role for several members of the bromodomain 
and extraterminal (BET) protein family, including bromodomain-containing proteins BRD2, BRD3 and BRD4, in the maintenance of aberrant chromatin states in AML, ALL, myeloma and lymphoma [2], [3], [4], [5].

BRD2/3/4 activate transcription by binding to acetyl-modified lysine residues of histone tails [6]. As chromatin scaffolds, they recruit elements of the positive transcriptional elongation factor $\mathrm{b}(\mathrm{P}-\mathrm{TEFb})$ complexes to RNA polymerase II (RNA Pol II) and initiate transcriptional elongation [7], [8]. Physiologically, $\mathrm{P}-\mathrm{TEFb}$-mediated elongation is regulated by the dynamic interplay of BRD4 and hexamethylene bisacetamide (HMBA) inducible protein 1 (HEXIM1) [9], [10]. BRD4 recruits $\mathrm{P}-\mathrm{TEFb}$ to active promoters via its affinity to acetylated histones, while HEXIM1 inactivates $\mathrm{P}-\mathrm{TEFb}$ via conformational changes and interaction of its C-terminal domain with 7SK snRNA [11]. In mice, c-MYC, a key regulator of cellular proliferation with oncogenic activity, has been shown to regulate $\mathrm{P}-\mathrm{TEFb}$ dependent pause release of Pol II [12].

BRD4 has been shown to drive oncogenetic processes by various mechanisms. The fusion protein BRD4-NUT is responsible for the aggressive NUT midline carcinoma [13], while interaction of BRD4 with acetylated NF- $\kappa \mathrm{B} /$ RelA leads to constitutively active NF-$\mathrm{B}$, enhancing cancer cell proliferation [14]. BRD4 also directly interacts with NPM1, MDM2 and p53 proteins, notably via HEXIM1. Wild type NPM1 represses BRD4 by reducing its affinity to chromatin. This negative regulation is impaired in NPM1-mutated AML [15], [16]. Knockdown of BRD4 in a shRNA screen demonstrated its critical role for maintenance of AML, as BRD4 inhibition resulted in antileukemic activity in vitro and in vivo [2], [17]. BRD2 associates with transcriptional coactivators and corepressors, regulates expression of cyclin A and D1, and acts as an atypical kinase with intrinsic chaperone activity [18]. Overexpression of BRD2 in murine B-cell progenitors induces a B-cell malignancy whose proteomic signature is reminiscent of human diffuse large B-cell lymphoma [19].

Inhibition of BET proteins thus constitutes an attractive therapeutic target. Pharmacologic BET inhibitors in development display significant activity in hematologic malignancies [20]. Treatment with the benzodiazepinederived inhibitor JQ1 recapitulated anti-leukemic effects of shRNA-induced suppression of BRD4 in several AML cell lines, mouse models and primary patient samples [2], and has also been associated with potent cell growth inhibition, cell cycle arrest and cell senescence, and decrease of c-MYC in three murine multiple myeloma cell lines [4]. The small molecule BET protein inhibitors I-BET151 and I-BET762, belonging to the quinoline class of BET inhibitors, have also demonstrated in vitro activity in hematologic malignancies, including mixed lineage leukemia-related AML and multiple myeloma [21], [22]. BET inhibition by these agents results in preferential loss of BRD4 bound to super-enhancers and by consequence causes transcriptional repression of $c-M Y C$ [23].

OTX015, a thienotriazolodiazepine compound and a JQ1 analog, has been shown to inhibit binding of $\mathrm{BRD} 2, \mathrm{BRD} 3$, and BRD4 to acetylated histone 4 in a concentration-dependent manner, suggesting competitive inhibition, with IC50 values from 92-112nM (Kay Noel, American association for Cancer Research, AACRNCI-EORTC International Conference on Molecular Targets and Cancer Therapeutics, Boston, MA, USA, oral communication, Oct 22, 2013). Here we studied the effects of OTX015 in a panel of leukemia cell lines, including the drug effects on cell growth, apoptosis and the expression of genes involved in the BRD2/3/4 signaling pathway. OTX015 was also evaluated ex vivo using primary cell samples from selected patients. OTX015 has entered clinical development in leukemia, with early results of an ongoing phase Ib study in advanced hematological tumors now available (Patrice Herait, AACR Annual Meeting, San Diego, LA, USA; Oral communication, Apr 04, 2014).

\section{RESULTS}

\section{Effect of OTX015 on cell proliferation, cell cycle and apoptosis in leukemia cell lines}

Cellular effects of OTX015 in various acute leukemia subtypes were evaluated. Cell viability after OTX015 exposure was assessed with the MTT assay in nine AML and four ALL cell lines. Significant growth inhibition, defined as a submicromolar IC50, was found in six of nine AML cell lines and all four ALL cell lines tested (Table 1). The K562 and KG1a AML cell lines were resistant to OTX015.

The effect of 500nM OTX015 exposure for $48 \mathrm{~h}$ on the cell cycle resulted in decreased transition from $\mathrm{G} 1$ to S-phase in all 13 cell lines and a significant increase in cells in the sub-G1 phase in KG1a, KG1, HEL, KASUMI and JURKAT cell lines (Figure 1A, 1B and supplementary Figure 1).

Treatment with OTX015 at doses from 25 to 500nM for $72 \mathrm{~h}$ induced significant apoptosis, as detected by Annexin V staining and PI uptake. At 500nM OTX015, $30-90 \%$ of cells were apoptotic in five of nine AML cell lines (HEL, NB4, NOMO-1, OCI-AML3, KASUMI) and $50-90 \%$ in two of four ALL cell lines (JURKAT and RS411; Figure 1C). Finally, $72 \mathrm{~h}$ exposure to 500nM OTX015 induced mitochondrial apoptosis by cytochrome $c$ release and caspase- 3 activation (Figure 1D). 
Table 1: IC50 in a panel of AML and ALL cell lines.

\begin{tabular}{|c|c|c|}
\hline AML cell line & Main genetic lesion & IC50 (nM) \\
\hline K562 & BCR-ABL & 11342 \\
\hline KG1a & OP2-FGFR1 & 1342 \\
\hline HL60 & NRAS Q61L & 248 \\
\hline HEL & JAK2 V617F & 233 \\
\hline NB4 & PML-RARa & 229 \\
\hline NOMO-1 & MLL-AF9 & 198 \\
\hline KG1 & OP2-FGFR1 & 17 \\
\hline OCI-AML3 & NPM1 A & IC50 (nM) \\
\hline Kasumi & AML1-ETO & 249 \\
\hline ALL cell line & Main genetic lesion & 161 \\
\hline JURKAT & PTEN del & 133 \\
\hline BV-173 & BCR-ABL & 34 \\
\hline TOM-1 & BCR-ABL & \\
\hline RS4-11 & MLL-AF4 & 17 \\
\hline
\end{tabular}

Thirteen AML and ALL cell lines were exposed to OTX015 $(0.01 \mathrm{nM}$ to $10 \mu \mathrm{M})$. Cell proliferation was measured by the MTT assay at $72 \mathrm{~h}$ and IC50 values were estimated. Experiments were performed in quadruplicates and means from three independent experiments are reported.

\section{Gene expression profiling of leukemic cell lines upon treatment with OTX015 and JQ1}

The patterns of gene expression after treatment with 500nM OTX015 and 500nM JQ1 for 24h were similar for both drugs compared to controls (Figure 2A). Applying a cutoff of $1 \mathrm{e}-3$ for the FDR and a cutoff of 0.9 for the log-fold-change in both comparisons, yielded signatures of 29 and 39 genes in the OTX015 vs. DMSO and the JQ1 vs. DMSO comparisons respectively. Among those genes, 27 were common to both signatures (Figure 2A, using a Fisher's exact test, the hypothesis of independence of both signatures was rejected; $p=2.2 \mathrm{e}-16$ ). In cell lines (NOMO1, OCI-AML3, HL60, KG1a and K562), molecular signatures of OTX015 treatment were similar for the sensitive HL60, NOMO-1 and OCI-AML3 cell lines, including decrease or increase of $c-M Y C$ and HEXIM1 expression (Figure 2B), whereas somewhat different expression patterns were noted for the less sensitive KG1a, and the resistant K562 cell lines.

Gene set enrichment analysis was performed for OTX015 or JQ1 vs. DMSO differential expression using the Gene Ontology Biological Process database $(n=$ 794 genes). Similar enrichment in a representative $M Y C$ dependent gene set [24] and a representative cell cycle gene set (Biological process GO:0007079) [25] were observed in all cell lines for OTX015 and JQ1 respectively (Figure 2C and 2D).

\section{Effects of OTX015 on c-MYC, BRD2/3/4 and HEXIM1 in acute leukemia cell lines}

Based on the results of the expression arrays experiments, we first evaluated the effects on c-MYC protein and mRNA expression after exposure to OTX015 at $500 \mathrm{nM}$ for $4,24,48$ or $72 \mathrm{~h}$ of in a panel of AL cell lines. Basal $c-M Y C$ gene expression varied among cell lines, with lowest levels observed in $B C R-A B L+\mathrm{K} 562$ cells and highest levels observed in the $P M L-R A R \alpha$ rearranged NB4 cell line (Figure 3A). Following exposure to OTX015, c-MYC protein and mRNA expression was analyzed. We observed a c-MYC protein decrease to a variable extent as early as $24 \mathrm{~h}$ after treatment in all cell lines tested, including AML cell lines (NPM1-mutated OCI-AML3, BCR-ABL+ K562, PML-RAR $\alpha$-rearranged NB4, MLL-AF9 fused NOMO1 and NRAS-driven HL60), and ALL cell lines (T-ALL JURKAT and MLL-AF4 fused B-ALL RS4-11 cells) (Figure 3B, supplementary Figure 2A). In line with these results, $c-M Y C$ mRNA decreased ubiquitously after $4 \mathrm{~h}$ and $24 \mathrm{~h}$ OTX015 exposure in these cell lines as well as in the OP2-FGFR1 rearranged KG1 AML cell line (Figure 3C). Treatment of these cell lines with 500nM JQ1 induced a decrease in c-MYC protein as seen with OTX015 at 24, 48 and 72h, as well as a similar $c-M Y C$ mRNA decrease at $48 \mathrm{~h}$ in all cell lines tested (supplementary Figure 2B and 2C, respectively).

We also studied the effects of OTX015 exposure on gene and protein expression of BRDs. Among AML cell lines, basal gene expression levels of BRDs were lowest in the BCR-ABL + K562 cell line and highest in 
$P M L-R A R \alpha$ rearranged NB4 (Figure 3D). After exposure to $500 \mathrm{nM}$ OTX015 for $48 \mathrm{~h} B R D 2, B R D 3$ and $B R D 4$ mRNA expression strongly decreased in the K562 and NB4 cell lines but increased in HL60 and NOMO-1 cells (Figure 3E). Only mild variations of $B R D 2, B R D 3$ and $B R D 4$ mRNA expression were observed in $\mathrm{KG} 1$, OCI-AML3, JURKAT, BV-173 and RS4-11. OTX015 induced a decrease in BRD2 protein in most cell lines, including OCI-AML3, JURKAT RS4-11, NB4, NOMO1 and HL60 cells but not in K562 cells (Figure 3B and supplementary Figure 2A). In contrast, decreased BRD4 protein after OTX015 treatment was only seen in the OCIAML3, NB4 and K562 cell lines. Finally, BRD3 protein levels were unmodified after OTX015 exposure in all cell lines analyzed (Figure 3B and supplementary Figure 2A). Compared to OTX015, treatment with JQ1 induced similar variations of BRD2, BRD3 and BRD4 proteins (supplementary Figure 2B).

The effect of OTX015 on HEXIM1 expression was evaluated. HEXIM1 mRNA expression increased both after 4 and 24h OTX015 exposure at 500nM in all cell lines tested (K562, HL-60, NB4, NOMO-1, KG1, OCI-AML3, JURKAT and RS4-11; Figure 3F). and was highest in OCI-AML3 and RS4-11 cell lines. Treatment with either OTX015 or JQ1 at 500nM (24-72h) yielded a similar increase in HEXIM1 protein levels after 24, 48 and 72h in OCI-AML3, JURKAT and RS4-11 cell lines but not in K562 cells (Figure 3B and supplementary Figure $2 \mathrm{~A}$ and $2 \mathrm{~B}$ ).

Finally, basal mRNA expression levels of $c-M Y C$, BRD2, BRD3, BRD4 and HEXIM1 did not significantly correlate with OTX015-induced loss of viability in any of the AML or ALL cell lines analyzed (supplementary Figure 3).
A

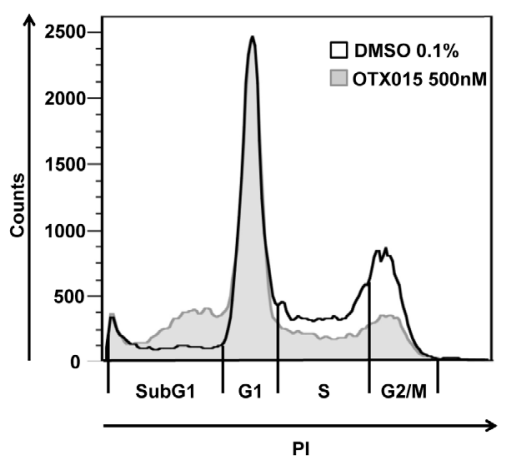

C

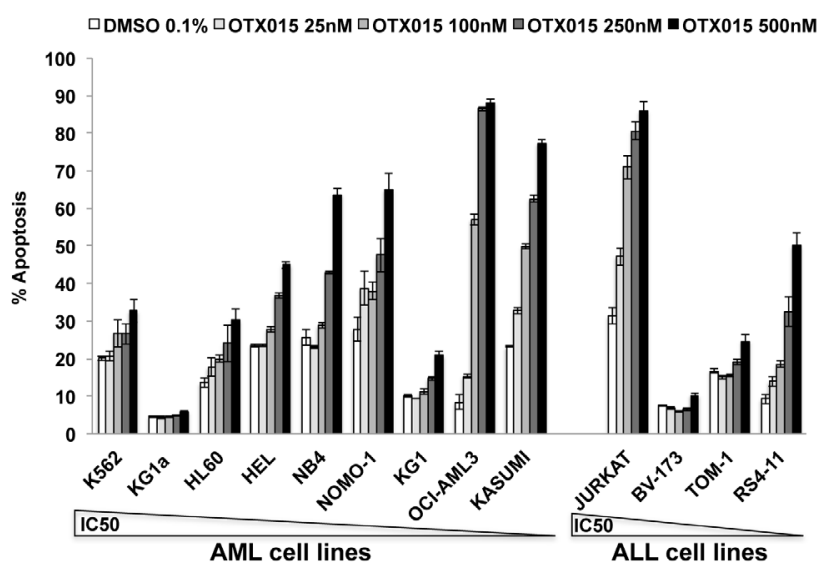

B

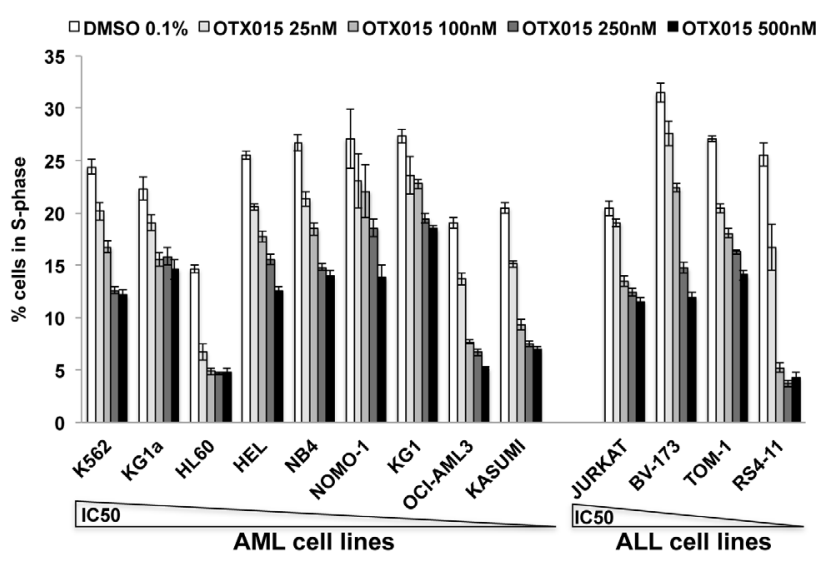

Figure 1: Effect of OTX015 on the cell cycle and apoptosis in AML and ALL cell lines. Cell cycle alterations at $48 \mathrm{~h}$ induced by increasing OTX015 doses (25nM-500nM) in leukemia cell lines: A. Representative flow cytometry overlay of the HEL cell line treated with 500nM OTX015 for 48h compared to 0.1\% DMSO and B. percent cells in S-phase for all cell lines. Results are shown as mean $+/-$ SEM from duplicates of three independent experiments. C. Apoptosis in AML and ALL cell lines after 72h exposure to increasing OTX015 doses (25nM-500nM). Apoptotic cells were defined as Annexin V+ with or without PI uptake. Results are shown as mean +/- SEM from duplicates of three independent experiments. D. Imunofluorescence for cytochrome $c$ and activated caspase-3 in NOMO- 1 cells after 72h exposure to 500nM OTX015 or 0.1\% DMSO. Cytochrome $c$ is shown in green, activated caspase-3 in red and nuclei are labelled blue. In non-apoptotic cells, cytochrome $c$ (green) shows dotted staining localized to mitochondria, while no activated caspase-3 is detected, and in apoptotic cells, cytochrome $c$ is released into the cytosol (green) and activated caspase- 3 is localized in the cytoplasm (red). Merged images of apoptotic cells appear in yellow. 


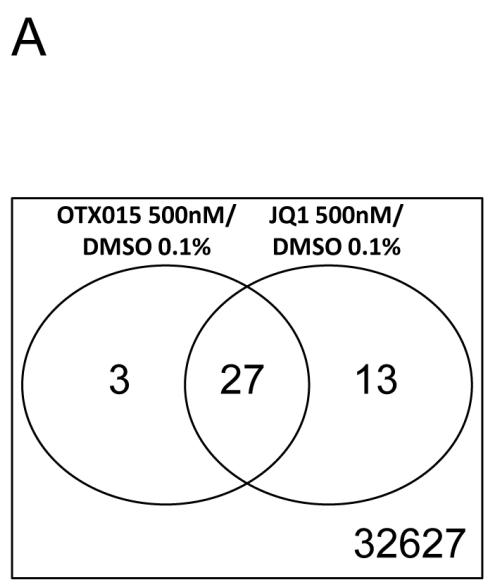

B

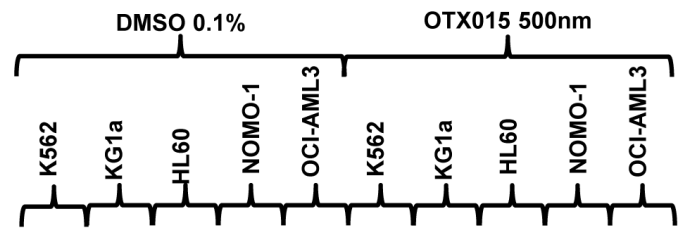

C

OTX015 500nM

Enrichment plot: MYC TARGETS

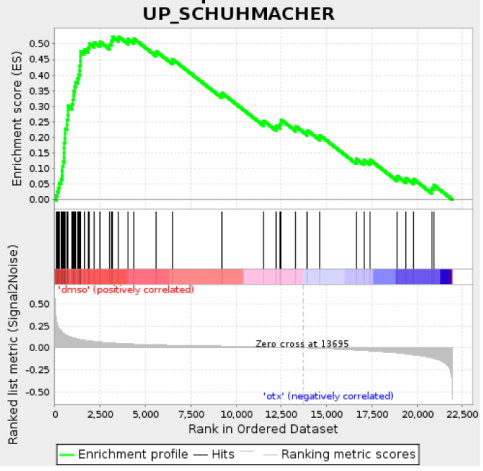

D OTX015 500nM

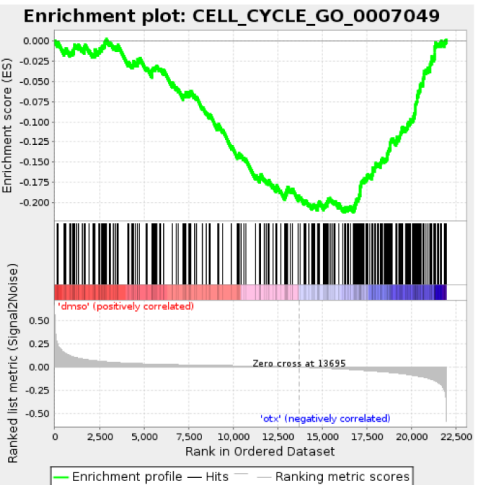

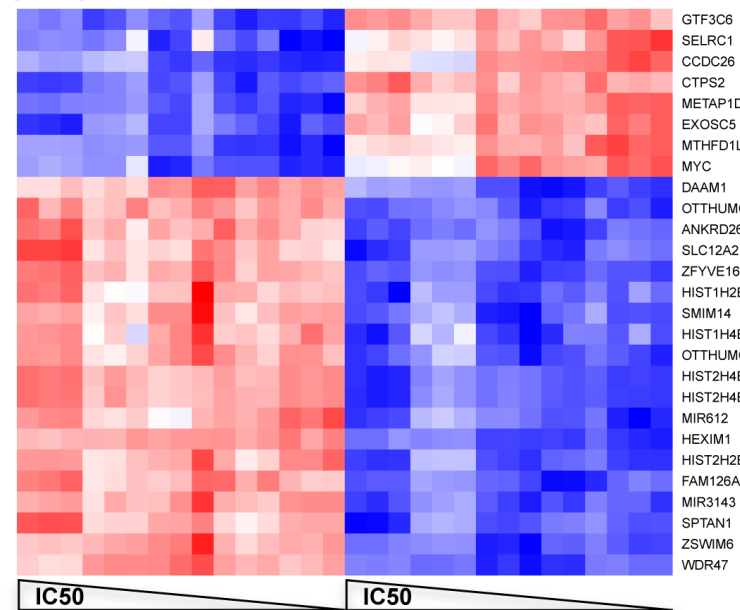

Color Key

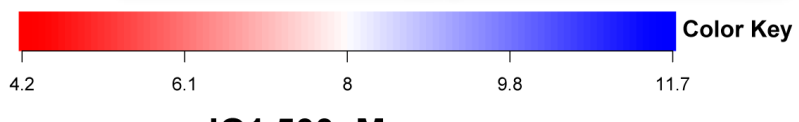

\section{JQ1 500nM}

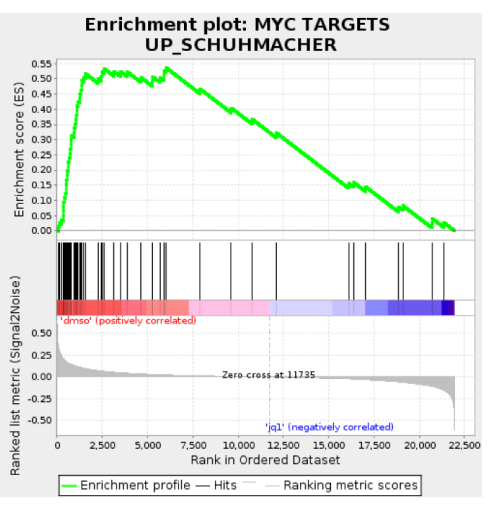

\section{JQ1 500nM}

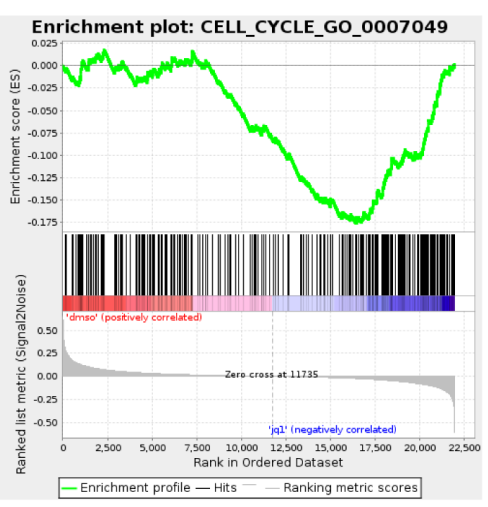

Figure 2: Molecular profiles after treatment with OTX015 and JQ1 in AML cell lines. GeneChip Human Transcriptome Array HTA 2.0 (Affymetrix ${ }^{\circledR}$ ) was performed for K562, KG1a, HL60, NOMO-1 and OCI-AML3 cells treated with either 500nM OTX015, $500 \mathrm{nM} \mathrm{JQ} 1$ or $0.1 \%$ DMSO for $24 \mathrm{~h}$. Experiments were performed as triplicates. A. Venn diagram of signatures of 29 and 39 genes in the OTX015 vs. DMSO contrast and the JQ1 vs. DMSO contrast respectively. B. Heatmap of the JQ1 and OTX015 commune signature showing differently regulated genes in cell lines after treatment with OTX015 500nM compared to DMSO 0,1\%. C. and D. MYC and cell cycle signatures enriched in all cell lines after treatment with OTX015 and JQ1. 
A

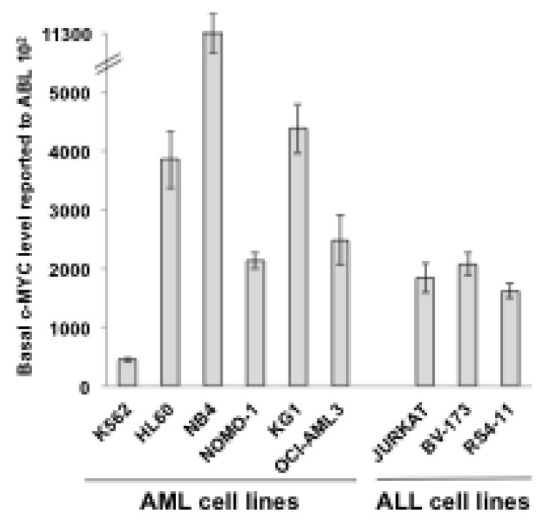

C

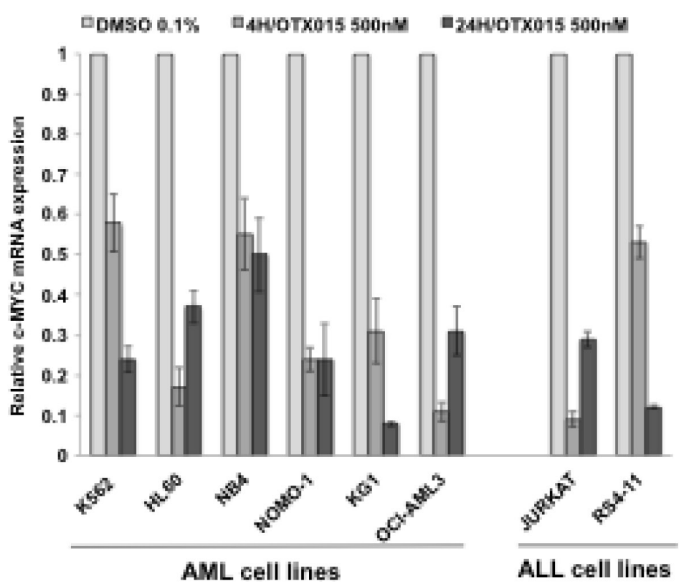

$\mathrm{E}$

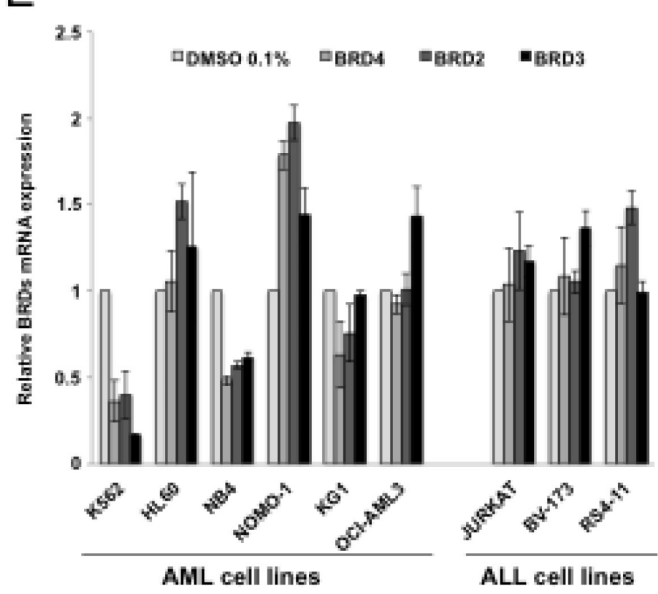

$\mathrm{B}$

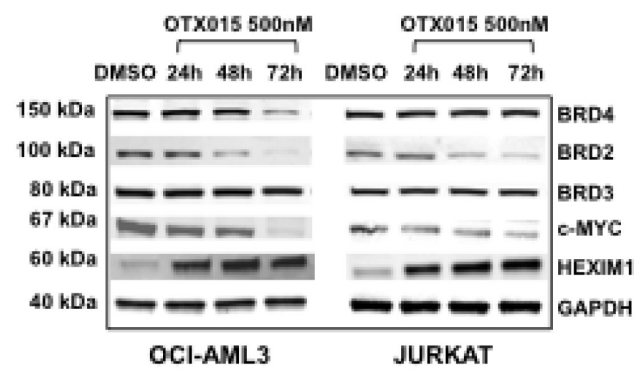

D

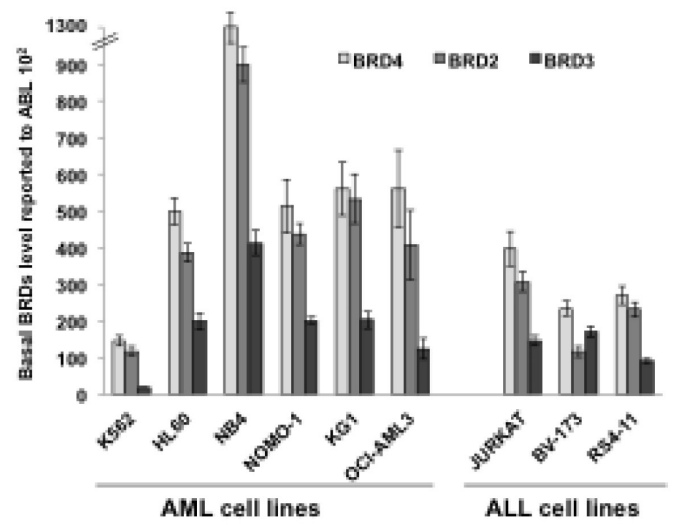

$\mathrm{F}$

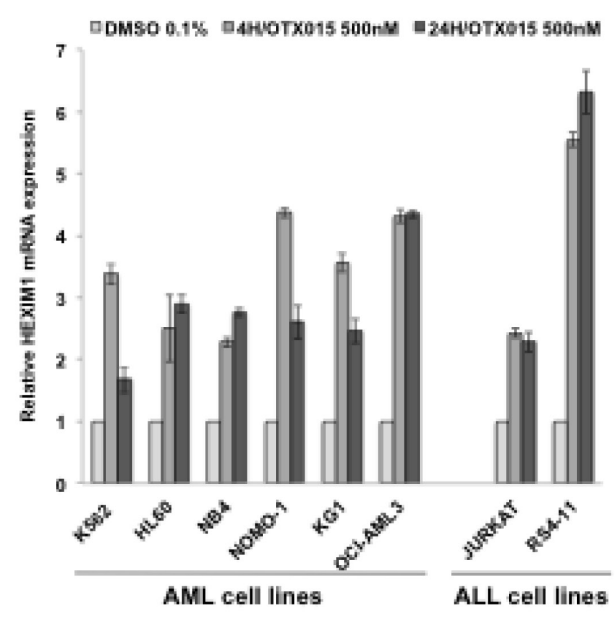

Figure 3: c-MYC, BRD2/3/4 and HEXIM1 expression in AML and ALL cell lines after OTX015 treatment. A. $c-M Y C$ basal gene expression in AML and ALL cell lines determined by RT-qPCR, relative to ABL $10^{2}$. Results are shown as mean $+/$ - SEM from duplicates of three independent experiments. B. Western blot showing c-MYC, BRD2/3/4, and HEXIM1 protein changes in OCIAML3 and JURKAT cells treated with 500nM OTX015 for 24, 48 or $72 \mathrm{~h}$ or $0.1 \%$ DMSO. GAPDH was used as a loading control. One representative experiment out of three is shown. C. RT-qPCR showing $c-M Y C$ decrease in AML and ALL cell lines after 4 and 24h exposure with 500nM OTX015, relative to GAPDH and normalized to $0.1 \%$ DMSO. Results are shown as mean +/- SEM from duplicates of three independent experiments. D. RT-qPCR showing $B R D 4, B R D 2$, and $B R D 3$ basal gene expression in leukemia cell lines, relative to ABL $10^{2}$. Results are shown as mean +/- SEM from duplicates of three independent experiments. E. RT-qPCR showing $B R D 4$, BRD2, and $B R D 3$ mRNA expression levels after $48 \mathrm{~h}$ exposure to $500 \mathrm{nM}$ OTX015 in leukemia cell lines, relative to $A B L$ and normalized to $0.1 \%$ DMSO. Results are shown as mean +/- SEM from duplicates of three independent experiments. F. RT-qPCR showing HEXIM1 mRNA increase in AML and ALL cell lines after $4 \mathrm{~h}$ and $24 \mathrm{~h}$ exposure with 500nM OTX015, relative to GAPDH and normalized to $0.1 \%$ DMSO. Results are shown as mean $+/$ - SEM from duplicates of three independent experiments. 
Table 2: Patient characterization and analyses performed.

\begin{tabular}{|c|c|c|c|c|c|c|c|}
\hline Patient $\mathrm{N}^{\circ}$ & Gender & Diagnosis & Karyotype & Molecular Biology & Apoptosis & mRNA & Protein \\
\hline 1 & $\mathrm{M}$ & AML 2 & $46 ; X Y ; \mathrm{t}(9 ; 11)$ & MLLT3-MLL & no & no & yes \\
\hline 2 & $\mathrm{M}$ & AML 2 & $46 ; X Y$ & CEBP alpha & no & yes & no \\
\hline 3 & $\mathrm{~F}$ & AML 1 & $46 ; \mathrm{XX}$ & FLT3 mut & yes & no & no \\
\hline 4 & $\mathrm{M}$ & sAML & $46 ; \mathrm{XY}$ & FLT3 mut & yes & no & no \\
\hline 5 & $\mathrm{M}$ & AML 2 & $46 ; X Y$ & dup MLL & no & yes & no \\
\hline 6 & $\mathrm{~F}$ & AML 1 & $46 ; \mathrm{XX}$ & dup MLL & no & yes & no \\
\hline 7 & $\mathrm{M}$ & AML 5a & $46 ; X Y$ & FLT3 ITD/ dup MLL & no & yes & no \\
\hline 8 & M & SAML & $46 ; X Y ; \operatorname{del}(3)(q ?),-7$ & FLT3 ITD / EVI1 & yes & no & no \\
\hline 9 & $\mathrm{M}$ & AML 5a & $46 ; X Y$ & FLT3 ITD & yes & no & no \\
\hline 10 & $\mathrm{~F}$ & AML 2 & $46 ; \mathrm{XX}$ & FLT3 ITD & no & yes & no \\
\hline 11 & $\mathrm{M}$ & AML & $46 ; X Y$ & FLT3 ITD & no & yes & no \\
\hline 12 & $\mathrm{~F}$ & AML & 47;XX; der(10)(?) & FLT3 ITD & no & yes & no \\
\hline 13 & $\mathrm{~F}$ & AML 1 & $46 ; \mathrm{XX}$ & NPM1 + FLT3 ITD & no & yes & no \\
\hline 14 & $\mathrm{~F}$ & sAML & $46 ; \mathrm{XX}$ & NPM1 + FLT3 ITD & yes & no & no \\
\hline 15 & $\mathrm{M}$ & AML 4 & $46 ; \mathrm{XY}$ & NPM1 + FLT3 ITD & yes & no & no \\
\hline 16 & $\mathrm{M}$ & AML 5 & $46 ; X Y$ & NPM1 + FLT3 ITD & yes & no & yes \\
\hline 17 & $\mathrm{M}$ & AML 4 & $46 ; X Y$ & NPM1 + FLT3 ITD & yes & no & no \\
\hline 18 & $\mathrm{M}$ & AML 2 & $46 ; \mathrm{XY}$ & NPM1 + FLT3 ITD & yes & no & no \\
\hline 19 & $\mathrm{~F}$ & AML 2 & $46 ; \mathrm{XX}$ & NPM1 & no & yes & no \\
\hline 20 & $\mathrm{~F}$ & AML 2 & $46 ; \mathrm{XX}$ & NPM1 & no & yes & no \\
\hline 21 & $\mathrm{M}$ & AML 4 & $46 ; \mathrm{XY}$ & NPM1 & no & yes & no \\
\hline 22 & $\mathrm{M}$ & AML 4 & $46 ; \mathrm{XY}$ & NPM1 & no & yes & no \\
\hline 23 & $\mathrm{~F}$ & AML 4 & $46 ; \mathrm{XX}$ & NPM1 & no & yes & no \\
\hline 24 & $\mathrm{M}$ & AML 1 & $46 ; X Y$ & NPM1 & no & yes & no \\
\hline 25 & $\mathrm{M}$ & AML 2 & $46 ; \mathrm{XY}$ & NPM1 & no & yes & no \\
\hline 26 & $\mathrm{~F}$ & AML 4eo & $46 ; X X ; \operatorname{inv}(16)(p 13 q 22)$ & $\mathrm{CBFb} / \mathrm{MYH11}$ & yes & yes & yes \\
\hline 27 & $\mathrm{~F}$ & AML 4eo & $46 ; X X ;$ inv(16)(p13q22) & $\mathrm{CBFb} / \mathrm{MYH11}$ & yes & yes & no \\
\hline 28 & $\mathrm{M}$ & AML 4eo & $46 ; X Y ;$ inv(16)(p13q22) & $\mathrm{CBFb} / \mathrm{MYH} 11$ & yes & yes & no \\
\hline 29 & $\mathrm{M}$ & AML 4eo & 46;XY; inv(16)(p13q22) & $\mathrm{CBFb} / \mathrm{MYH} 11$ & no & yes & no \\
\hline 30 & $\mathrm{~F}$ & AML 4eo & $46 ; X X ; \operatorname{inv}(16)(p 13 q 22)$ & $\mathrm{CBFb} / \mathrm{MYH11}$ & no & yes & no \\
\hline 31 & $\mathrm{~F}$ & AML 2 & $46 ; X X ; \mathrm{t}(8 ; 21)$ & AML1-ETO & yes & no & no \\
\hline 32 & $\mathrm{M}$ & AML 2 & $46 ; X Y ; \mathrm{t}(8 ; 21)$ & AML1-ETO & no & yes & no \\
\hline 33 & $\mathrm{M}$ & AML 2 & $46 ; X Y ; t(8 ; 21)$ & AML1-ETO & no & yes & no \\
\hline 34 & $\mathrm{~F}$ & AML & Complex & ND & no & yes & no \\
\hline 35 & $\mathrm{~F}$ & AML & Complex & ND & no & yes & no \\
\hline 36 & $\mathrm{M}$ & AML & Complex & ND & no & yes & no \\
\hline 37 & $\mathrm{M}$ & AML & Complex & ND & no & yes & no \\
\hline 38 & $\mathrm{~F}$ & AML 5 & Complex & $\mathrm{ND}$ & yes & yes & no \\
\hline 39 & $\mathrm{~F}$ & ALL-B & Complex & Ikaros del & no & yes & no \\
\hline 40 & $\mathrm{~F}$ & ALL-B & Complex & Ikaros del & yes & yes & no \\
\hline 41 & $\mathrm{M}$ & ALL-B & $46 ; X Y$ & ND & no & yes & no \\
\hline
\end{tabular}




\begin{tabular}{|c|c|c|c|c|c|c|c|}
\hline Patient $\mathbf{N}^{\circ}$ & Gender & Diagnosis & Karyotype & Molecular Biology & Apoptosis & mRNA & Protein \\
\hline 42 & $\mathrm{~F}$ & ALL-B & $46 ; \mathrm{XX}$ & ND & no & yes & no \\
\hline 43 & M & ALL-B & $46 ; \mathrm{XY} ; \mathrm{t}(9 ; 22)$ & BCR-ABL & yes & no & yes \\
\hline 44 & M & ALL-B & $46 ; \mathrm{XY} ; \mathrm{t}(9 ; 22)$ & BCR-ABL & no & yes & no \\
\hline 45 & F & ALL-B & $46 ; \mathrm{XX} ; \mathrm{t}(9 ; 22)$ & BCR-ABL & no & yes & no \\
\hline 46 & M & ALL-B & $46 ; \mathrm{XY} ; \mathrm{t}(9 ; 22)$ & BCR-ABL & no & yes & no \\
\hline 47 & M & ALL-B & $46 ; \mathrm{XY} ; \mathrm{t}(9 ; 22)$ & BCR-ABL & no & yes & no \\
\hline 48 & M & ALL-T & $46 ; \mathrm{XY} ; \operatorname{del}(7)(\mathrm{p} ?)$ & HOX11L2 & no & yes & no \\
\hline 49 & F & ALL-T & Complex & ND & no & yes & no \\
\hline 50 & F & ALL-T & Complex & ND & no & yes & no \\
\hline 51 & M & ALL-T & Complex & ND & no & yes & no \\
\hline 52 & M & ALL-T & ND & Calm/Af10 & no & yes & no \\
\hline
\end{tabular}

F, female; M, male; ND, not determined

\section{Ex vivo effects of OTX015 in leukemic patient- derived samples}

Apoptosis, mRNA and protein expression were evaluated in BM mononuclear cells obtained from representative newly diagnosed or relapsed ALL and AML patients for whom sufficient material for analysis was available (Table 2). Apoptosis induction by exposure to $500 \mathrm{nM}$ OTX015 for $72 \mathrm{~h}$ was variable among the patient samples tested (Figure 4A). BM cells from 8 of 14 AML patients showed increased apoptosis ranging from $35-90 \%$ with OTX015 compared to control-treated cells (patients 3, 15, 17, 26, 27, 28, 31 and 38), while no or a mild increase in apoptosis was observed after OTX015 exposure in 6 of 14 patients (patients 4, 8, 9, 14, 16 and 18). BM cells from the two ALL patients tested showed no or a mild increase in apoptosis (patients 40 and 43).

We obtained CD34+ cells from six healthy donors. Apoptosis was assessed after $72 \mathrm{~h}$ and OTX015 induced no significant apoptosis after $72 \mathrm{~h}$ exposure in cells from 2 donors, while slight apoptosis was observed in 1 donor (supplementary Figure 4A). Clonogenicity assays showed no significant inhibition of colony growth for 2 patients while colony growth was inhibited in 1 patient (supplementary Figure 4B).

In line with our observations in cell lines, OTX015 also induced activation of caspase-3 and mitochondrial cytochrome $c$ release in samples analyzed from three AML patients (Figure 4B).

After treatment with $500 \mathrm{nM}$ OTX015 for $48 \mathrm{~h}$, $c-M Y C$ mRNA decreased in the seven AML samples and two ALL samples (Figure 4C) evaluated. In three primary AML samples analyzed, c-MYC protein clearly decreased after $72 \mathrm{~h}$ with $500 \mathrm{nM}$ OTX015, as did BRD2 protein (Figure 4D).

We studied basal BRD2/3/4 gene expression in 38 AML and 14 ALL patient samples of various subtypes. As observed in cell lines, gene expression levels were highly variable across AML and ALL subtypes with the lowest expression in bcr-abl rearranged ALL samples (Figure 4E, supplementary Figure 5 and Table 2).

\section{Simultaneous and sequential treatment of KASUMI cell line with OTX015, azacitidine and panobinostat}

We searched for synergistic effects of OTX015 on growth $(7-600 \mathrm{nM})$ if combined to other epigenetic modifying drugs: either azacitidine $(123 \mathrm{nM}-10 \mu \mathrm{M})$ or panobinostat $(0.1-10 \mathrm{nM})$. Synergy, was observed with both, simultaneous treatment of KASUMI cells by OTX015 and azacitidine (CI: 0.89 ) and sequential treatments, either OTX015 followed by azacitidine (CI: 0.76) or azacitidine followed by OTX015 (CI: 0.68) (Figure 5A). Synergy was significantly stronger when azacitidine was followed by OTX015 compared to simultaneous treatment with both drugs $(p=0.03)$. Significantly stronger synergy was observed during sequential treatments with either OTX015 followed by panobinostat or panobinostat followed by OTX015 (CI: 0.83 and 0.78 respectively) compared to simultaneous treatment (CI: $0.93 ; p=0.0001$ and 0.01 respectively) (Figure 5B).

\section{DISCUSSION}

Treatment of acute leukemia remains a major clinical challenge, with disappointing long-term outcome of the majority of adult patients. AML is predominantly a disease of older patients, with overall survival of less than $10-20 \%$ in this age group [26]. Novel treatment strategies with acceptable toxicity are urgently needed to improve outcome. Here we demonstrate for the first time, that the oral BRD2/3/4 inhibitor OTX015, which is 


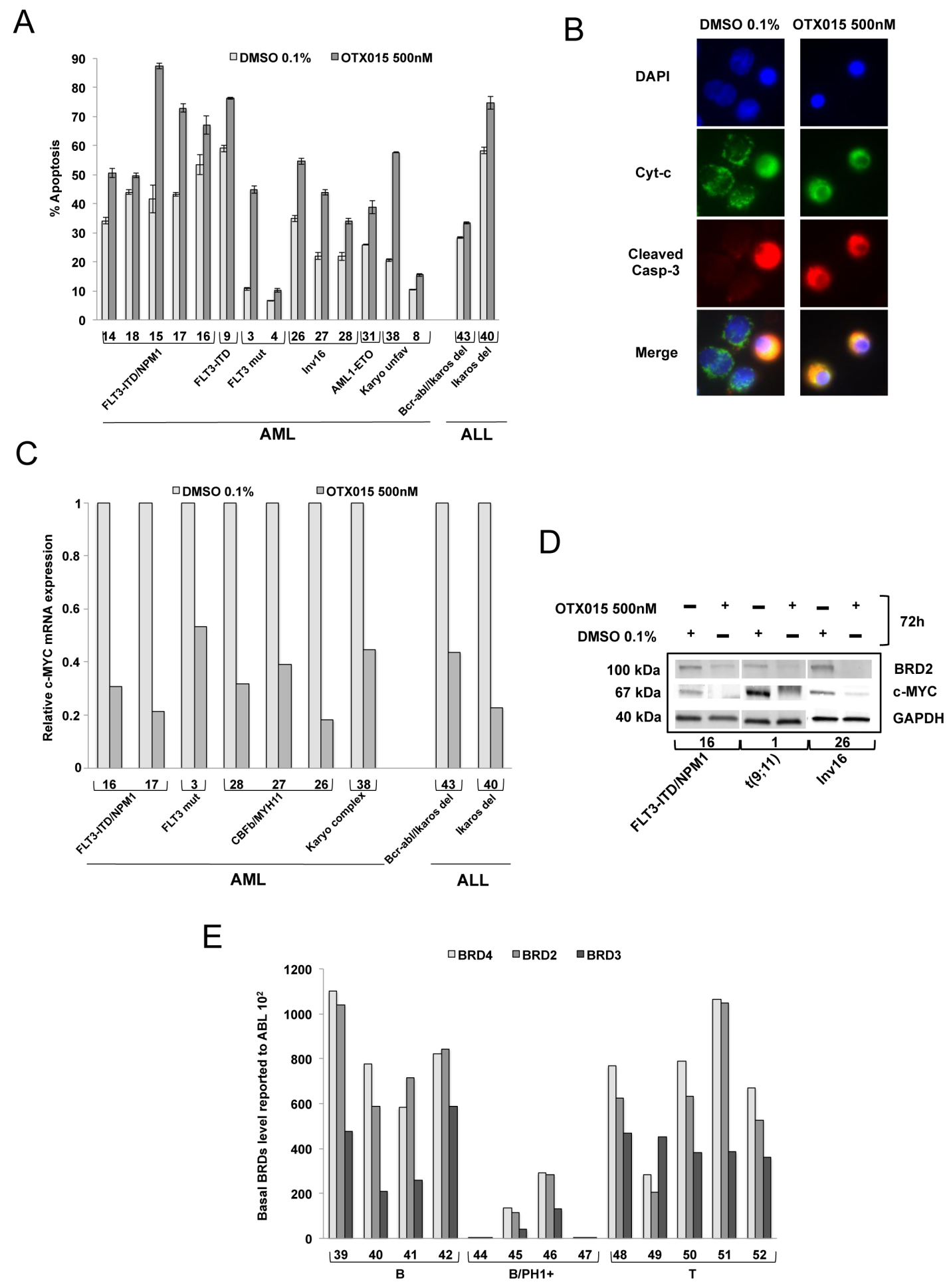

Figure 4: Induction of apoptosis, expression of c-MYC and BRD2 following OTX015, and basal expression of BRD2/3/4 in AML and ALL patient samples. A. Bone marrow mononuclear cells were exposed to 500nM OTX015 for $72 \mathrm{~h}$. Apoptotic cells were defined as Annexin V+ with or without PI uptake. Results are shown as mean +/- SEM. B. BM cells from a patient with MLL-rearranged AML (MLL-AF9) (Patient 1, Table 2) showing cytochrome $c$ (green), activated caspase-3 (red) and nuclei (blue). In non-apoptotic cells cytochrome $c$ (green) shows dotted staining localized in the mitochondria while no activated caspase-3 could be detected, and in apoptotic cells cytochrome $c$ is released into the cytosol (green) and activated caspase-3 is localized to the cytoplasm (red). Merged images of apoptotic cells appear in yellow. C. RT-qPCR showing $c-M Y C$ mRNA expression in nine AML and ALL patient samples after 72h exposure with 500nM OTX015 or $0.1 \%$ DMSO, relative to $A B L$ normalized to $0.1 \%$ DMSO. D. Western blot showing BRD2, c-MYC and GAPDH expression in three AML patient samples exposed $72 \mathrm{~h}$ to $500 \mathrm{nM}$ OTX015 or $0.1 \%$ DMSO ex vivo. E. RT-qPCR showing BRD4, BRD2, and $B R D 3$ basal gene expression levels in $13 \mathrm{ALL}$ patient samples, relative to $A B L 10^{2}$. 
already in early clinical development in acute leukemia patients, has similar biological effects compared to JQ1, a prototypic $\mathrm{BRD}$ inhibitor, although restricted to in vitro use, in a broad range of acute leukemia cell lines and patient-derived leukemic samples. In most leukemic cell lines, relevant biological effects were observed in the submicromolar range with IC50 values and very similar for OTX015 and JQ1 [2]. In line, we observed cell cycle arrest in the G1/S transition and apoptosis rates as reported for JQ1.

The concentration range for which most biologic effects were observed can be achieved in vivo, as demonstrated in patients currently treated by OTX015 in the ongoing phase Ib clinical trial in refractory hematologic malignancies, in which promising antitumor activity has been seen in both leukemia and lymphoma patients (Patrice Herait, AACR Annual Meeting, San Diego, LA, USA; Oral communication, Apr 04, 2014). Available pharmacokinetics data indicate that this activity was detected with an OTX015 dosing and schedule giving plasma trough levels of approximately $250 \mathrm{nM}$.

In line with reported outcomes for BET inhibitors JQ1 and I-BET in acute leukemia and other hematologic malignancies [2], [4], OTX015 also decreased c-MYC mRNA or protein as shown in the majority of the cell lines, as well as in primary acute leukemia samples. These observations confirm that c-MYC decrease is a major class effect of these drugs. A recent publication also confirmed that MYC is a key downstream target of BRD4-NUT [27], associated with an aggressive form of squamous cell carcinoma.

We show here that OTX015 exposure decreases BRD2 and BRD4 proteins, while BRD3 expression remained unaffected. Indeed it has been shown that that pharmacologic or shRNA inhibition of BRD4 protein expression leads to similar biologic effects [2]. More recently, inhibition of BRD2 by siRNA knockdown or treatment with JQ1 was shown to inhibit constitutive STAT5 activity in a large panel of acute leukemia and lymphoma cell lines [26]. In particular, strong synergy towards induced apoptosis was described when combined with tyrosine kinase inhibitors. It has also been demonstrated that the BET inhibitors I-BET151 and I-BET762 (currently under clinical investigation in NUTmidline carcinoma) exert their biologic activity via BRD2 decrease [20]. Our findings with OTX015 also suggest that BRD2 decrease participates in the anti-leukemic activity of OTX015. Further studies are needed to dissect the roles of BRD2 and BRD4 in OTX015 biologic effects [28].

Exposure to OTX015 or JQ1 increases HEXIM1 protein and mRNA expression [10]. Our findings of increased HEXIM1 gene expression after treatment with OTX015 are in line with those reported with either JQ1 or I-BET151, in multiple myeloma and ALL [3], [4], [22]. Overexpression of HEXIM1 leads to limited availability of active $\mathrm{P}-\mathrm{TEFb}$ as a result of sustained BET inhibition in myeloma cells having a significant impact on the transcription of a large number of genes, including oncogenic MYC [29]. In line, OTX015 induced HEXIM1 overexpression may similarly intervene in the effects we observed in AL cell lines and AML patient samples.

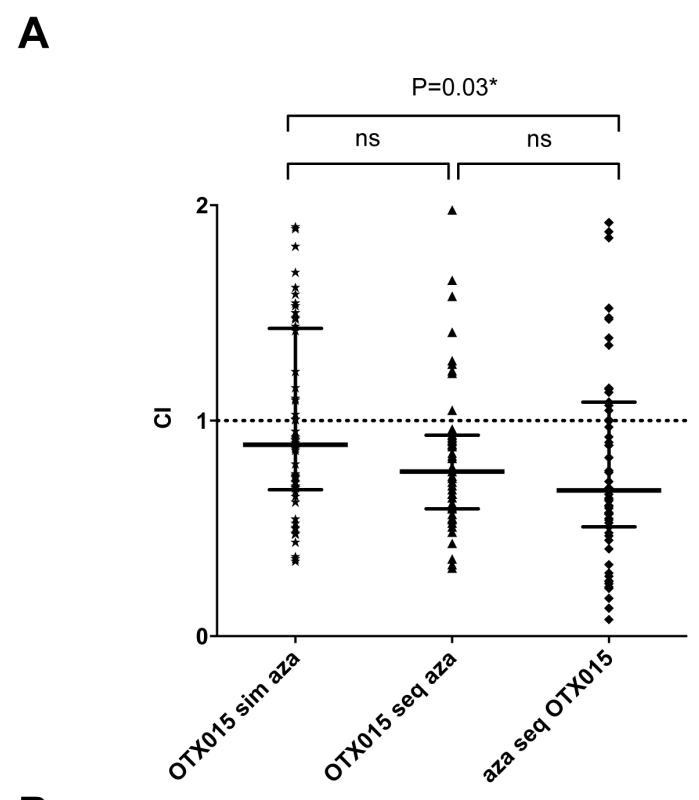

B

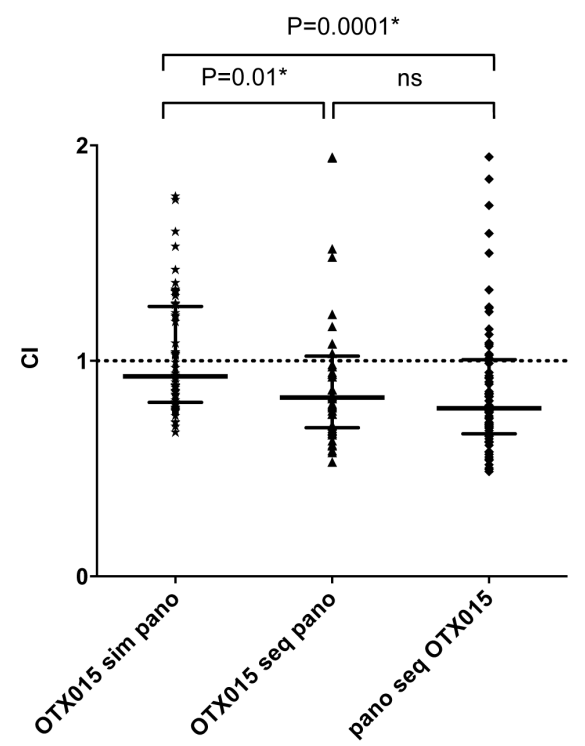

Figure 5: Simultaneous and sequential treatment of KASUMI cells with OTX015 and azacitidine and panobinostat show additional and synergic effects. Combination Index (CI) versus Fractional Effect (FE) plots were calculated using CalcuSyn ${ }^{\circledR}$ Software Version 2.1. Median CI of different dose combinations (simultaneous and sequential) were calculated for OTX 015 and azacitidine A. or OTX015 and panobinostat B.. CI values $<0.9$ indicate synergy. Median CI values were calculated as median with interquartile range from three independent experiments and compared by the MannWhitney test. 
OTX015 exposure induced growth inhibition, blocked cell cycle G1-S transition and caused apoptosis in acute leukemia cell lines and patient-derived leukemic samples, as previously reported for other preclinical BET inhibitors including JQ1 and I-BET151 [21], [30]. MLL fusion is associated with the BET family of acetyl-lysine recognizing chromatin adaptor proteins [21]. Similar to previous reports of BET inhibitors being highly active in MLL-fused leukemic cells, we show here that the MLL gene-rearranged NOMO-1 and RS4-11 leukemia cell lines are particularly sensitive to OTX015 [2], [3], [21], [31]. The NPM1-mutated cell line OCI-AML3 was also highly sensitive to OTX015, confirming results reported by Dawson et al [16] showing efficacy of I-BET151 in this cell line, as well as in a murine model of NPM1-mutated AML and in primary patient samples harboring NPMI mutations.

Interestingly, we were unable to identify any correlations between reductions of cell viability or induction of apoptosis and $c-M Y C, B R D 2 / 3 / 4$ and HEXIM1 expression levels in cell lines exposed to OTX015 (supplementary Figure 3). c-MYC decrease and HEXIM1 increase induced by OTX015 was observed in all the cell lines analyzed, as reported with other BET inhibitors (supplementary Figure 6) .

Recently, elegant studies in mouse models have shown that BET inhibition specifically targets recurrent genetic lesions in AML including IDH2 and FLT3-ITD mutations, complete or interstitial chromosome 7 deletion, and $\operatorname{inv}(3) / \mathrm{t}(3 ; 3)$ associated with aberrant EVI1 expression [32], [33], [34]. Importantly, all of these genetic lesions are associated with a poor prognosis in patients treated with standard chemotherapy regimens [35]. BET inhibition has also been reported to target chemoresistant, 'persister' cells in T-ALL [36]. Thus, OTX015 might also be a promising therapeutic option for this subset of chemoresistant acute leukemia subtypes.

Epigenetic modifying drugs like the hypomethylating agent azacitidine and the histone deacetylase inhibitor panobinostat hold promise in the treatment of patients with AML uneligible for intensive treatment [37]. Furthermore it has recently been shown that targeting histone deacetylases in $\mathrm{t}(8 ; 21)$ AML constitutes a potential molecular target [38]. In line, we have tested combinations of OTX015 with azacitidine and panobinostat in the $t(8 ; 21)$ KASUMI AML cell line. Simultaneous treatments mostly lead to additive effects while a strong synergy was observed with a sequential treatment with azacitidine followed by OTX015. This confirms earlier observations of synergic effects of combinations of the BET inhibitor JQ1 and AML chemotherapy (i.e.Cytarabine) [30] .

On the other hand, to date, no mechanisms leading to resistance of BET inhibition have been identified. BCRABL driven K562 was the only cell line to be clearly resistant, but BCR-ABL T-ALL cell lines BV-173 and
TOM-1 were highly sensitive to OTX015 treatment, which hints to other resistance mechanisms in K562 cells. Of note, the anti apoptotic gene $B C L 2$ was among the top ten of up-regulated genes in K562 cells as compared to OCIAML 3 cells upon treatment with OTX015, indicating that up-regulation of anti apoptotic pathways could be implicated in resistance of K562 cells (supplementary Table 2). Nevertheless, somewhat different expression patterns for resistant K562 and less sensitive KG1a cells compared to other more sensitive cell lines were observed.

We have demonstrated that the BET inhibitor OTX015 decreases the expression of BRD2, BRD4 and $\mathrm{c}-\mathrm{MYC}$ and increases the expression of the MYC negative regulator HEXIM1 as the BET-inhibitor JQ1 probe. Our data comfort the use of OTX015 in the ongoing phase $1 \mathrm{~b}$ clinical trial in refractory hematologic malignancies including acute leukemias, and future studies in this indication.

\section{MATERIALS AND METHODS}

\section{Cell lines and selection of primary patient cells}

A panel of representative ALL and AML cell lines was purchased from Deutsche Sammlung von Mikroorganismen und Zellkulturen (DSMZ). ALL cell lines used were JURKAT (T-ALL), RS4-11 (MLL-AF4 B-precursor ALL), TOM-1, BV-173 (both Ph+ ALL). AML cell lines used were $\mathrm{K} 562(\mathrm{Ph}+\mathrm{CML}$ in blast crisis), HL60 (NRAS-driven AML M2), NOMO-1 (MLL$A F 9$-driven AML), KG1 (OP2-FGRF1 AML M6) and its more immature subtype KG1a, HEL (JAK2 V617F), OCIAML3 (NPM1 and DNMT3A mutations), NB4 (PML$R A R \alpha)$ and KASUMI (AML1-ETO). Cells were cultured in RPMI 1640 (Life Technologies) supplemented with $10 \%$ or $20 \%$ heat-inactivated fetal calf serum for ALL and AML lines respectively, $2 \mathrm{mM}$ L-glutamine, $100 \mathrm{IU} / \mathrm{mL}$ penicillin, $100 \mu \mathrm{g} / \mathrm{mL}$ streptomycin and HEPES, at $37^{\circ} \mathrm{C}$ with $5 \% \mathrm{CO}_{2}$.

Mononuclear cells from the bone marrow (BM) of selected AML and ALL patients were isolated by FicollPaque PLUS density gradient (Amersham Biosciences). Primary cells were maintained in IMDM (Life Technologies) supplemented with $10 \%$ heat-inactivated fetal calf serum, $2 \mathrm{mM}$ L-glutamine, $100 \mathrm{IU} / \mathrm{mL}$ penicillin, and $100 \mu \mathrm{g} / \mathrm{mL}$ streptomycin without growth factors, at $37^{\circ} \mathrm{C}$ with $5 \% \mathrm{CO}_{2}$. Patients provided informed consent prior to BM aspiration at diagnosis, according to the Declaration of Helsinki. Approval for this study was obtained from the local institutional review board. 


\section{Compounds}

OTX015 (2-[(6S)-4-(4-Chlorophenyl)-2,3,9trimethyl-6H-thieno[3,2-f][1,2,4]triazolo-[4,3-a][1,4] diazepin-6-yl]-N-(4-hydroxyphenyl) acetamide) was provided by Oncoethix (Lausanne, Switzerland) and $(+)-$ JQ1 (tert-butyl 2-((6S)-4-(4-chlorophenyl)-2,3,9-trimethyl$6 \mathrm{H}$-thieno[3,2-f][1,2,4]triazolo[4,3-a][1,4]diazepin-6-yl) acetate) was purchased from BPS Bioscience. Azacitidine (4-amino-1- $\beta$-D-ribofuranosyl-1,3,5-triazin-2(1H)-1) and panobinostat ([E]-N-hydroxy-3-4-((2-(2-methyl1H-indol-3-yl)ethylamino)methyl)phenyl)-acrylamide were purchased from Selleckchem. All compounds were dissolved in dimethyl sulfoxide (DMSO; 1.0M stock solution) and stored at $-80^{\circ} \mathrm{C}$. Aliquots were thawed and used immediately for serial dilution in culture media. Control cells were incubated with $0.1 \%$ DMSO.

\section{MTT assay, apoptosis assessment and cell cycle analysis}

For the MTT assay, cells were seeded in 24well plates at $1 \times 10^{6}$ per well and treated with a range of OTX015 concentrations $0.01 \mathrm{nM}-10 \mu \mathrm{M}$ for $72 \mathrm{~h}$. Cells were transferred to 96-well plates and incubated with $\quad 0.5 \mathrm{mg} / \mathrm{mL} \quad 3$-(4,5-dimethylthiazol-2-yl)-2,5diphenyltetrazolium bromide (MTT, Molecular Probes) in the dark at $37^{\circ} \mathrm{C}$ for $4 \mathrm{~h}$. Cells were then lysed with $25 \%$ sodium dodecyl sulfate (SDS) lysis buffer and absorbance was read at $570 \mathrm{~nm}$ using a Promega Microplate Reader. Three independent experiments were run for each cell line and untreated cells were used as negative controls. The half maximal inhibitory concentration (IC50) values were calculated with Prism ${ }^{\circledR}$ v6 software (GraphPad Inc).

For cell cycle analysis, $1 \times 10^{6}$ cells were treated with a range of OTX015 concentrations $25-500 \mathrm{nM}$ for $48 \mathrm{~h}$ then harvested, washed in PBS, and fixed in 70\% ice cold ethanol. Cells were incubated with $100 \mu \mathrm{g} / \mathrm{mL}$ RNAse (Sigma) and stained with $25 \mu \mathrm{g} / \mathrm{mL}$ propidium iodide (PI; Becton Dickinson) for 30 minutes at $37^{\circ} \mathrm{C}$.

For apoptosis analysis, $1 \times 10^{6}$ cells derived from patients or cell lines were resuspended in $1 \mathrm{ml}$ culture medium and treated with OTX015 for $72 \mathrm{~h}$. Apoptotic cells were detected using a FACSCalibur flow cytometer (Becton Dickinson). Cells were stained with $5 \mu \mathrm{g} / \mathrm{mL}$ PI and Annexin-V-FITC (Becton Dickinson) according to the manufacturer's instructions for 15 minutes at room temperature. Apoptotic cells were defined as Annexin V+ with or without PI uptake.

Cell cycle distribution and apoptosis were determined by cytofluorometric analysis using a FACSCalibur flow cytometer (Becton Dickinson) and analyzed with the FlowJo flow cytometry software (TreeStar Inc).

\section{Immunofluorescence}

Cells were allowed to adhere to polylysine-L slides (Thermo Scientific) and analyzed using an Image-iT ${ }^{\circledR}$ Fixation/Permeabilization Kit (Life Technologies). Briefly, cells were fixed for 15 minutes with $4 \%$ paraformaldehyde in PBS ( $\mathrm{pH} 7.3)$ at room temperature, then permeabilized with Triton X-100 $0.5 \%$ for 15 minutes and blocked for 1 hour with 3\% BSA in DPBS (pH7.4). Cells were incubated with cleaved caspase-3 antibody (rabbit monoclonal Ab 9664; Cell Signaling Technology) or cytochrome $c$ antibody (mouse monoclonal Ab 556432; Becton Dickinson) overnight at $4^{\circ} \mathrm{C}$. Secondary antibodies were goat anti-rabbit and goat anti-mouse IgG coupled with Alexa 568 (red) or Alexa 488 (green) fluorochromes (Life Technologies) incubated at $37^{\circ} \mathrm{C}$ for $2 \mathrm{~h}$. Nuclei were counterstained with DAPI (Vector). Images were acquired by immunofluorescence microscopy on a Zeiss Axiovert microscope with a Plan-Apochromat X63 N.A.1.4 oil immersion objective using the Axiovison software v4.2 (Carl Zeiss).

\section{Quantitative-real time polymerase chain reaction (RT-qPCR)}

Total RNA after extraction with TRIzol (Invitrogen) was titrated to $1 \mu \mathrm{g} / \mu \mathrm{L}$ with a NanoDrop 2000c UV-Vis spectrophotometer (Thermo Scientific) and stored at $-80^{\circ} \mathrm{C}$. Complementary DNA (cDNA) was synthesized from $1 \mu \mathrm{g}$ RNA with a reverse transcriptase M-MLV $\mathrm{Kit}^{\circledR}$ (Life Technologies) using Random Hexamer Primers (Thermo Scientific). RT-qPCR reactions (BRD2, BRD3, $B R D 4, c-M Y C, H E X I M 1, G A P D H$ and $A B L)$ were performed in $25 \mu \mathrm{l}$ from one- tenth of the cDNA volume (100 ng RNA), using a thermocycler ABI7900HT (Life Technologies) with TaqMan reagent or a StepOnePlus (Life Technologies) with SYBR Green reagent (Roche) in standard mode ( 1 cycle of 2 minutes at $50^{\circ} \mathrm{C}$ then 10 minutes at $95^{\circ} \mathrm{C}$ followed by 50 cycles of 15 seconds at $95^{\circ} \mathrm{C}$ then 1 minute at $60^{\circ} \mathrm{C}$ ) with a supplementary melting curve step for SYBR Green assays. Primers (Eurogentec) are listed in supplementary Table 1. mRNA levels were normalized to $A B L$ control gene.

\section{Gene expression profiling}

NOMO-1, OCI-AML3, HL60, KG1a and K562 cells were treated for 24 hours either with $500 \mathrm{nM}$ OTX015, 500nM JQ1 or $0.1 \%$ DMSO (vehicle). Total RNA was extracted from corresponding cell lines. $500 \mathrm{ng}$ of RNA of each sample was processed using the WT PLUS Amplification and Labeling Kit according to the manufacturer's instructions, and analyzed with the GeneChip Human Transcriptome Array HTA 2.0 Array 
$\left(\right.$ Affymetrix ${ }^{\circledR}$ ). This covers 44,699 coding transcripts, and 22829 non-coding transcripts. The WT plus Reagent Kit generates amplified and biotinylated sensestrand DNA targets from total RNA. Each sample was hybridized on the array, washed, and stained with the Affymetrix $^{\circledR}$ Fluidics Station 450. They were scanned with the Affymetrix ${ }^{\circledR}$ GeneChip Scanner $30007 \mathrm{G}$ using the Command Console software (Affymetrix ${ }^{\circledR}$ ) then analysed using the Affymetrix ${ }^{\circledR}$ rma-sketch routine. A total of 72 chips were included in the quality control and normalization. OTX015-treated (500nM) $(n=3$ replicates, time point $24 \mathrm{~h})$, JQ1-treated cells $(500 \mathrm{nM})(n$ $=3$ replicates, time point $24 \mathrm{~h}$ ), DMSO $0.1 \%$-treated cells ( $n=3$ replicates, time point $24 \mathrm{~h}$ ) and untreated control cells ( $n=3$ replicates, time point $24 \mathrm{~h}$ ).

Differential gene expression was assessed using the Bioconductor limma library on annotated coding transcripts $(n=32670)$. The multiple hypothesis testing issue was adressed using the False Discovery Rate (FDR) approach of Benjamini and Hochberg [39]. Metabolic pathways analysis was performed using the GSEA v2.0 software with 1000 gene set permutations.

\section{Immunoblotting}

Protein was extracted from $7 \times 10^{6}$ cells exposed to either OTX015, JQ1 or 0.1\% DMSO; 30 $\mu$ g was loaded on SDS-polyacrylamide gels using $4-15 \%$ gradient gels (Bio-Rad) and transferred to nitrocellulose membranes using a Mini Trans-Blot Electrophoretic Transfer cell (Bio-Rad). Membranes were blocked with blocking buffer (LICOR) and incubated with the primary antibody overnight at $4^{\circ} \mathrm{C}$ : anti-BRD4 (\#5716-1, Epitomics), antiBRD3 (ab56342, AbCam), anti-BRD2 (ab37633, AbCam), anti-c-MYC (\#sc-764 [N262], supplier), anti-HEXIM1 (\#sc-365413, Santa Cruz) or anti-GAPDH (\#398600, Invitrogen). Secondary antibodies were goat anti-rabbit InfraRedDye 680RD or goat anti-mouse InfraRedDye $800 \mathrm{CW}$ (LICOR), incubated for $2 \mathrm{~h}$ at room temperature. Bands were visualized using a LiCor Odyssey scanner. For BRD2, membranes were secondarily stained with goat (BRD2) anti-rabbit peroxidase-labeled or goat anti-mouse (GAPDH) peroxidase-labeled secondary antibody (Bio$\mathrm{Rad}$ ) and visualized with an enhanced chemiluminescence detection system (ECL or ECL plus, GE Healthcare).

\section{Drug-dose-response experiments and CalcuSyn ${ }^{\circledR}$ analysis}

In combination experiments of OTX015 with azacitidine or panobinostat, compounds were added simultaneously or sequentially and relative cell numbers were determined at $48 \mathrm{~h}$ with MTT assays. IC50 values were calculated with Prism ${ }^{\circledR}$ v6 software (GraphPad Inc) at various concentrations of OTX015, azacitidine and panobinostat. Combination index (CI) values were calculated with CalcuSyn ${ }^{\circledR}$ Version 2.1 software (Biosoft, Cambridge, UK) according to the Chow and Talalay model [40].

\section{Statistical analysis}

Correlations between gene expression and cell viability were assessed using a Pearson's correlation coefficient. Statistically significant differences in CI for different drug combinations were calculated from medians compared by the Mann-Whitney U test. A heatmap for genes of interest was computed with the R software (www. cran.r-project.org).

\section{ACKNOWLEDGMENTS}

We thank Sarah MacKenzie (OTD) for helpful comments and medical writing editorial assistance. We thank Lucile Astxer for technical assistance for combination experiments.

MMC received a research grant from Assistance Publique-Hopitaux de Paris (Medaille d'Or des Internes des Hopitaux de Paris).

\section{CONFLICTS OF INTEREST}

HD received research funding from Oncoethix.

MER is an employee of OTD who receives funding from Oncoethix.

$\mathrm{PH}$ is the Chief Medical Officer and a shareholder of Oncoethix.

MMC, TB, JB, MD, MDe, SB, AM, ER, RI, AB, $\mathrm{CG}$ have no conflicts of interest.

\section{GRANT SUPPORT}

MMC received a research grant from Assistance Publique-Hopitaux de Paris (Medaille d'Or des Internes des Hopitaux de Paris).

\section{Authorship Contributions}

MMC, TB, JB, MD and SB performed experiments; MMC, TB, JB, MD, SB, AM, RI, AB, MER, HD and $\mathrm{CG}$ designed experiments and analyzed data; MMC, TB, $\mathrm{HD}, \mathrm{ER}$ and CG provided patient samples; MMC, PH and MER contributed essential reagents; MDe performed bioinformatic analysis; MMC, TB, JB, MD, RI, AB, HD and $\mathrm{CG}$ prepared the manuscript. All authors reviewed and approved the final manuscript. 


\section{REFERENCES}

1. Patel KP, Barkoh BA, Chen Z, Ma D, Reddy N, Medeiros LJ and Luthra R. Diagnostic testing for IDH1 and IDH2 variants in acute myeloid leukemia an algorithmic approach using high-resolution melting curve analysis. The Journal of molecular diagnostics : JMD. 2011; 13:678-686.

2. Zuber J, Shi J, Wang E, Rappaport AR, Herrmann H, Sison EA, Magoon D, Qi J, Blatt K, Wunderlich M, Taylor MJ, Johns C, Chicas A, Mulloy JC, Kogan SC, Brown P, et al. RNAi screen identifies Brd4 as a therapeutic target in acute myeloid leukaemia. Nature. 2011; 478:524-528.

3. Ott CJ, Kopp N, Bird L, Paranal RM, Qi J, Bowman T, Rodig SJ, Kung AL, Bradner JE and Weinstock DM. BET bromodomain inhibition targets both c-Myc and IL7R in high-risk acute lymphoblastic leukemia. Blood. 2012; 120:2843-2852.

4. Delmore JE, Issa GC, Lemieux ME, Rahl PB, Shi J, Jacobs HM, Kastritis E, Gilpatrick T, Paranal RM, Qi J, Chesi M, Schinzel AC, McKeown MR, Heffernan TP, Vakoc CR, Bergsagel PL, et al. BET bromodomain inhibition as a therapeutic strategy to target c-Myc. Cell. 2011; 146:904917.

5. Emadali A, Rousseaux S, Bruder-Costa J, Rome C, Duley S, Hamaidia S, Betton P, Debernardi A, Leroux D, Bernay B, Kieffer-Jaquinod S, Combes F, Ferri E, McKenna CE, Petosa C, Bruley $\mathrm{C}$, et al. Identification of a novel BET bromodomain inhibitor-sensitive, gene regulatory circuit that controls Rituximab response and tumour growth in aggressive lymphoid cancers. EMBO molecular medicine. 2013; 5:1180-1195.

6. Yang Z, Zheng C, Thiriet C and Hayes JJ. The core histone $\mathrm{N}$-terminal tail domains negatively regulate binding of transcription factor IIIA to a nucleosome containing a $5 \mathrm{~S}$ RNA gene via a novel mechanism. Molecular and cellular biology. 2005; 25:241-249.

7. Bisgrove DA, Mahmoudi T, Henklein P and Verdin E. Conserved P-TEFb-interacting domain of BRD4 inhibits HIV transcription. Proceedings of the National Academy of Sciences of the United States of America. 2007; 104:1369013695.

8. Nechaev S and Adelman K. Pol II waiting in the starting gates: Regulating the transition from transcription initiation into productive elongation. Biochimica et biophysica acta. 2011; 1809:34-45.

9. Zhou Q and Yik JH. The Yin and Yang of P-TEFb regulation: implications for human immunodeficiency virus gene expression and global control of cell growth and differentiation. Microbiology and molecular biology reviews : MMBR. 2006; 70:646-659.

10. Dey A, Chao SH and Lane DP. HEXIM1 and the control of transcription elongation: from cancer and inflammation to AIDS and cardiac hypertrophy. Cell cycle. 2007; 6:18561863.
11. Yik JH, Chen R, Nishimura R, Jennings JL, Link AJ and Zhou Q. Inhibition of P-TEFb (CDK9/Cyclin T) kinase and RNA polymerase II transcription by the coordinated actions of HEXIM1 and 7SK snRNA. Molecular cell. 2003; 12:971-982.

12. Rahl PB, Lin CY, Seila AC, Flynn RA, McCuine S, Burge CB, Sharp PA and Young RA. c-Myc regulates transcriptional pause release. Cell. 2010; 141:432-445.

13. French CA, Miyoshi I, Kubonishi I, Grier HE, Perez-Atayde AR and Fletcher JA. BRD4-NUT fusion oncogene: a novel mechanism in aggressive carcinoma. Cancer research. 2003; 63:304-307.

14. Huang B, Yang XD, Zhou MM, Ozato K and Chen LF. Brd4 coactivates transcriptional activation of NF-kappaB via specific binding to acetylated RelA. Molecular and cellular biology. 2009; 29:1375-1387.

15. Gurumurthy M, Tan CH, Ng R, Zeiger L, Lau J, Lee J, Dey A, Philp R, Li Q, Lim TM, Price DH, Lane DP and Chao SH. Nucleophosmin interacts with HEXIM1 and regulates RNA polymerase II transcription. Journal of molecular biology. 2008; 378:302-317.

16. Dawson MA, Gudgin EJ, Horton SJ, Giotopoulos G, Meduri E, Robson S, Cannizzaro E, Osaki H, Wiese M, Putwain S, Fong CY, Grove C, Craig J, Dittmann A, Lugo D, Jeffrey P, et al. Recurrent mutations, including NPM1c, activate a BRD4-dependent core transcriptional program in acute myeloid leukemia. Leukemia. 2014; 28:311-320.

17. Blobel GA, Kalota A, Sanchez PV and Carroll M. Short hairpin RNA screen reveals bromodomain proteins as novel targets in acute myeloid leukemia. Cancer cell. 2011; 20:287-288.

18. LeRoy G, Rickards B and Flint SJ. The double bromodomain proteins $\operatorname{Brd} 2$ and $\operatorname{Brd} 3$ couple histone acetylation to transcription. Molecular cell. 2008; 30:51-60.

19. Romesser PB, Perlman DH, Faller DV, Costello $\mathrm{CE}, \mathrm{McComb} \mathrm{ME}$ and Denis GV. Development of a malignancy-associated proteomic signature for diffuse large B-cell lymphoma. The American journal of pathology. 2009; 175:25-35.

20. Garnier JM, Sharp PP and Burns CJ. BET bromodomain inhibitors: a patent review. Expert opinion on therapeutic patents. 2014; 24:185-199.

21. Dawson MA, Prinjha RK, Dittmann A, Giotopoulos G, Bantscheff M, Chan WI, Robson SC, Chung CW, Hopf C, Savitski MM, Huthmacher C, Gudgin E, Lugo D, Beinke $\mathrm{S}$, Chapman TD, Roberts EJ, et al. Inhibition of BET recruitment to chromatin as an effective treatment for MLLfusion leukaemia. Nature. 2011; 478:529-533.

22. Chaidos A, Caputo V, Gouvedenou K, Liu B, Marigo I, Chaudhry MS, Rotolo A, Tough DF, Smithers NN, Bassil AK, Chapman TD, Harker NR, Barbash O, Tummino P, AlMahdi N, Haynes AC, et al. Potent antimyeloma activity of the novel bromodomain inhibitors I-BET151 and I-BET762. Blood. 2014; 123:697-705. 
23. Loven J, Hoke HA, Lin CY, Lau A, Orlando DA, Vakoc CR, Bradner JE, Lee TI and Young RA. Selective inhibition of tumor oncogenes by disruption of super-enhancers. Cell. 2013; 153:320-334.

24. Schuhmacher M, Kohlhuber F, Holzel M, Kaiser C, Burtscher H, Jarsch M, Bornkamm GW, Laux G, Polack A, Weidle UH and Eick D. The transcriptional program of a human B cell line in response to Myc. Nucleic acids research. 2001; 29:397-406.

25. Ashburner M, Ball CA, Blake JA, Botstein D, Butler H, Cherry JM, Davis AP, Dolinski K, Dwight SS, Eppig JT, Harris MA, Hill DP, Issel-Tarver L, Kasarskis A, Lewis S, Matese JC, et al. Gene ontology: tool for the unification of biology. The Gene Ontology Consortium. Nature genetics. 2000; 25:25-29.

26. Estey E and Dohner H. Acute myeloid leukaemia. Lancet. 2006; 368:1894-1907.

27. Grayson AR, Walsh EM, Cameron MJ, Godec J, Ashworth T, Ambrose JM, Aserlind AB, Wang H, Evan GI, Kluk MJ, Bradner JE, Aster JC and French CA. MYC, a downstream target of BRD-NUT, is necessary and sufficient for the blockade of differentiation in NUT midline carcinoma. Oncogene. 2014; 33:1736-1742.

28. Liu S, Walker SR, Nelson EA, Cerulli R, Xiang M, Toniolo PA, Qi J, Stone RM, Wadleigh M, Bradner JE and Frank DA. Targeting STAT5 in hematologic malignancies through inhibition of the bromodomain and extra-terminal (BET) bromodomain protein BRD2. Molecular cancer therapeutics. 2014; 13:1194-1205.

29. Diribarne G and Bensaude O. 7SK RNA, a non-coding RNA regulating $\mathrm{P}-\mathrm{TEFb}$, a general transcription factor. RNA biology. 2009; 6:122-128.

30. Herrmann H, Blatt K, Shi J, Gleixner KV, Cerny-Reiterer S, Mullauer L, Vakoc CR, Sperr WR, Horny HP, Bradner JE, Zuber J and Valent P. Small-molecule inhibition of BRD4 as a new potent approach to eliminate leukemic stem- and progenitor cells in acute myeloid leukemia AML. Oncotarget. 2012; 3:1588-1599.

31. Valent P and Zuber J. BRD4: a BET(ter) target for the treatment of AML? Cell cycle. 2014; 13:689-690.

32. Chen C, Liu Y, Lu C, Cross JR, Morris JPt, Shroff AS, Ward PS, Bradner JE, Thompson C and Lowe SW. Cancerassociated IDH2 mutants drive an acute myeloid leukemia that is susceptible to Brd4 inhibition. Genes \& development. 2013; 27:1974-1985.

33. Chen C, Liu Y, Rappaport AR, Kitzing T, Schultz N, Zhao Z, Shroff AS, Dickins RA, Vakoc CR, Bradner JE, Stock W, LeBeau MM, Shannon KM, Kogan S, Zuber J and Lowe SW. MLL3 is a haploinsufficient 7q tumor suppressor in acute myeloid leukemia. Cancer cell. 2014; 25:652-665.

34. Groschel S, Sanders MA, Hoogenboezem R, de Wit E, Bouwman BA, Erpelinck C, van der Velden VH, Havermans M, Avellino R, van Lom K, Rombouts EJ, van Duin M, Dohner K, Beverloo HB, Bradner JE, Dohner H, et al. A single oncogenic enhancer rearrangement causes concomitant EVI1 and GATA2 deregulation in leukemia. Cell. 2014; 157:369-381.

35. Mrozek K, Marcucci G, Nicolet D, Maharry KS, Becker $\mathrm{H}$, Whitman SP, Metzeler KH, Schwind S, Wu YZ, Kohlschmidt J, Pettenati MJ, Heerema NA, Block AW, Patil SR, Baer MR, Kolitz JE, et al. Prognostic significance of the European LeukemiaNet standardized system for reporting cytogenetic and molecular alterations in adults with acute myeloid leukemia. Journal of clinical oncology : official journal of the American Society of Clinical Oncology. 2012; 30:4515-4523.

36. Knoechel B, Roderick JE, Williamson KE, Zhu J, Lohr JG, Cotton MJ, Gillespie SM, Fernandez D, Ku M, Wang H, Piccioni F, Silver SJ, Jain M, Pearson D, Kluk MJ, Ott CJ, et al. An epigenetic mechanism of resistance to targeted therapy in $\mathrm{T}$ cell acute lymphoblastic leukemia. Nature genetics. 2014; 46:364-370.

37. Montalban-Bravo G and Garcia-Manero G. Novel drugs for older patients with acute myeloid leukemia. Leukemia. 2014.

38. Bots M, Verbrugge I, Martin BP, Salmon JM, Ghisi M, Baker A, Stanley K, Shortt J, Ossenkoppele GJ, Zuber J, Rappaport AR, Atadja P, Lowe SW and Johnstone RW. Differentiation therapy for the treatment of $t(8 ; 21)$ acute myeloid leukemia using histone deacetylase inhibitors. Blood. 2014; 123:1341-1352.

39. Benjamini Y, Drai D, Elmer G, Kafkafi N and Golani I. Controlling the false discovery rate in behavior genetics research. Behavioural brain research. 2001; 125:279-284.

40. Reynolds CP and Maurer BJ. Evaluating response to antineoplastic drug combinations in tissue culture models. Methods in molecular medicine. 2005; 110:173-183. 